\title{
Effects of Pfaffia glomerata (Spreng) Pedersen Aqueous Extract on Healing Acetic Acid-induced Ulcers
}

\author{
Cristina Setim Freitas, Cristiane Hatsuko Baggio, Samanta Luiza Araújo, Maria Consuelo \\ Andrade Marques* \\ Departamento de Farmacologia; Setor de Ciências Biológicas; Universidade Federal do Paraná; Centro \\ Politécnico; C.P.: 19031; mconsu@ufpr.br; 81531-990; Curitiba - PR - Brasil
}

\begin{abstract}
The present study was carried out to evaluate the acute toxicity and the effect of the aqueous extract of the roots from Pfaffia glomerata (Spreng) Pedersen (Amaranthaceae) (AEP) on the prevention of acetic acid-induced ulcer and on the healing process of previously induced ulcers. The acute toxicity was evaluated in Swiss mice after oral administration of a single dose and the chronic gastric ulcer was induced with local application of acetic acid. The results showed that the $L D_{50}$ of the extract was $684.6 \mathrm{mg} . \mathrm{kg}^{-1}$ for the intraperitoneal administration and higher than $10 \mathrm{mg} . \mathrm{kg}^{-1}$ by the oral route. The administration of the AEP did not prevent ulcers formation. However, the AEP increased of the healing process of previously induced ulcers. The results suggest that AEP chronically administered promote an increase of tissue healing, after the damage induced by acetic acid and the extract seemed to be destituted of toxic effects in the mice by the oral route.
\end{abstract}

Keywords: Pfaffia glomerata, crude extract, healing ulcers, gastric mucosa

\section{INTRODUCTION}

The genus Pfaffia belongs to Amaranthaceae family and several species are commercialized in Brazil as substitutes for the Asian ginseng (Panax spp, Araliaceae). They are popularly known as "Brazilian ginseng" and have been used as tonic and aphrodisiac, as well as for the treatment of gastric disturbances and healing of the wounds (Oliveira, 1986). The main components isolated so far from Pfaffia spp. roots are stigmasterol, sitosterol, allantoin, pfaffic acid and their glycosides (nortriterpenoids), triterpenoids and ecdysteroids (Nishimoto et al., 1984; Nakai, 1984; Shiobara et al., 1993; Takemoto, 1983). These triterpene saponins have been considered to be potential antitumourals (Nishimoto et al., 1984). A study done with the hydroalcoholic extract obtained from a mix of the roots from the distinct species of Pfaffia showed the protection of the gastric mucosa against ethanol- and stress-induced ulcers and reduction of the basal and bethanecholor histamine-stimulated gastric acid secretion (Freitas et al., 2003). Other study reported that the crude aqueous extract of Pfaffia glomerata (AEP) protected the gastric mucosa against ethanol- and stress-induced mucosal lesions and inhibited gastric acid secretion in the rats, probably through the inhibition of the histaminergic pathway and/or the enhancement of the gastric nitric oxide production (Freitas et al., 2004). The aim of this study was to evaluate the effects of the crude

\footnotetext{
${ }^{*}$ Author for correspondence
} 
aqueous extract of $P$. glomerata (AEP) on the prevention of acetic acid induced ulcers and on the healing process on previously induced ulcers, besides the safety of its utilization by the population.

\section{MATERIAL AND METHODS}

\section{Plant material}

Pfaffia glomerata (Spreng) Pedersen was harvested from the banks and islands of Paraná River in the city of Querência do Norte, PR, Brazil. Cirino Corrêa Júnior (EMATER-PR) did the collection and identification. A voucher specimen has been deposited in the Herbarium of the Department of Botany in the Universidade Federal do Paraná, Brazil, under number UPCB 38.609. The roots and rhizomes were reduced to small pieces, dried in a circulating air stove and triturated. The powder was extracted $(10 \% \mathrm{w} / \mathrm{v})$ with the hot water $\left(73{ }^{\circ} \mathrm{C}\right)$ during $30 \mathrm{~min}$. The aqueous extract was concentrated under vacuum to $1 / 4$ of the original volume, lyophilized and stored under light protection and low temperature $\left(-5^{\circ} \mathrm{C}\right)$. The yield of the lyophilized extract was $39 \%$, relating to the dried subterraneous parts. The phytochemical characterization made through high performance liquid chromatography analyses (HPLC-DAD) revealed that $P$. glomerata contained around $0.37 \%$ of $\beta$-ecdysone, a marker of this plant (Freitas et al., 2004).

\section{Animals}

The rats and mice were obtained from the animal facilities of Universidade Federal do Paraná and were maintained under the standard laboratory conditions ( $12 \mathrm{~h}$ light/dark cycle, temperature $22 \pm$ $\left.2{ }^{\circ} \mathrm{C}\right)$. Standard pellet food (Nuvital ${ }^{\circledR}$, Curitiba/PR, Brazil) and water were available ad libitum. Three days before the treatment, the rats were submitted to an alimentary diet where they received the food twice a day for one hour (9:30-10:30 am and 3:304:30 pm). The institutional Ethics Committee of the Universidade Federal do Paraná (Brazil) approved all the procedures described here.

\section{Hippocratic test and lethal dose $50 \%\left(\mathrm{LD}_{50}\right)$}

Non-fasted mice (both sexes, $\mathrm{n}=10 / \mathrm{sex}$ ) were treated with AEP $\left(1,2,4,8\right.$ and $10 \mathrm{~g} \cdot \mathrm{kg}^{-1}$, po or $0.1,0.3,0.6,1$ and $\left.1.5 \mathrm{~g} . \mathrm{kg}^{-1}, i p\right)$. The animals were observed continuously for one hour, followed by every hour up to $6 \mathrm{~h}$ and by 14 days for any changes in the behavior and manifestations of the toxic symptoms according to Malone (Malone, 1977). The LD-15 was determined within 24 hours after the treatment.

\section{Acetic acid-induced ulcer model}

The ulcers were induced by the local application of acetic acid to serosal surface of the stomach as described earlier (Takagi et al., 1969). Under anesthesia midline incision was made and the stomach was taken out. On the serosal surface of the glandular portion of stomach $50 \mu \mathrm{l}$ of $2.5 \%$ and $5.0 \%$ acetic acid (anterior gastric wall) and 50 $\mu \mathrm{l}$ of $10.0 \%$ acetic acid and $0.9 \%$ saline (posterior gastric wall) were injected. One day after the ulcer induction, the rats were given AEP intragastrically at doses of $0.5,1.0$ and $1.5 \mathrm{~g} . \mathrm{kg}^{-1}$ twice a day for 7 days to observe the ulcer-prevention effect. To observe the ulcer healing, at the $7^{\text {th }}$ day after the surgery, the animals were treated with AEP (0.5, 1.0 and $1.5 \mathrm{~g} . \mathrm{kg}^{-1}, \mathrm{po}$ ) twice a day for 7 days. After the treatment, the rats were sacrificed and the ulcers size (index of mucosal damage) in the anterior and posterior walls were determined and summed in each stomach.

All the animals were subjected to a gross autopsy (WHO, 1993 and OECD, 1998) and stomachs were removed and weighed, fixed in $10 \%$ neutral buffered formalin, embedded in the paraffin wax, sectioned at $5 \mu \mathrm{m}$, stained with hematoxylin and eosin and then examined by the light microscopy.

\section{Statistical analysis}

Lichfield and Wilcoxon statistical method was used to determine the LD-50 (Lichfield and Wilcoxon, 1948). Statistical significance of the healing ulcer results were determined using oneway analysis of variance (ANOVA), followed by Tukey Kramer tests. Data were considered different at a significance level of $p<0.05$. Data were expressed as mean \pm s.e.m.

\section{RESULTS AND DISCUSSION}

The $\mathrm{LD}_{50}$ of AEP administered by ip route in the mice was $684.6 \mathrm{mg} . \mathrm{kg}^{-1}$ within $24 \mathrm{~h}$ after the acute administration, with upper and lower reliability limits of 968.4 and $484.0 \mathrm{mg} \cdot \mathrm{kg}^{-1}$, respectively. Acute administration of $\mathrm{AE}$ in the doses up to $10 \mathrm{~g} \cdot \mathrm{kg}^{-1}(p o)$ did not cause the death of animals. 
All the animals that received AEP ip presented the abdominal constriction on the first 5 minutes after the administration. The administration of AEP to the animals produced a decrease of the motor activity starting $5 \mathrm{~min}$ after the administration of the extract and lasting up to $5 \mathrm{~h}$ after the treatment, a palpebral ptosis, pilomotor erection and respiratory alterations from $4 \mathrm{~min}$ to $2 \mathrm{~h}$ after the administration of the extract. The animals that received the higher doses (1.0 and $\left.1.5 \mathrm{~g} \cdot \mathrm{kg}^{-1}\right)$ presented alienation and passivity from $1 \mathrm{~h}$ to the death and the dose of $0.6 \mathrm{~g} \cdot \mathrm{kg}^{-1}$ presented the same effects until $5 \mathrm{~h}$ after the administration.

The orally treatment with AEP (doses up to 2.0 g. $\mathrm{kg}^{-1}$ ) did not promote the perceptible alterations on the behavior of the animals. After the oral administration of higher doses (4.0, 8.0 and 10.0 $\mathrm{g} . \mathrm{kg}^{-1}$ ) similar effects provoked by the ip administration were observed, differing in the latency time and the needed dose to induce the effects.

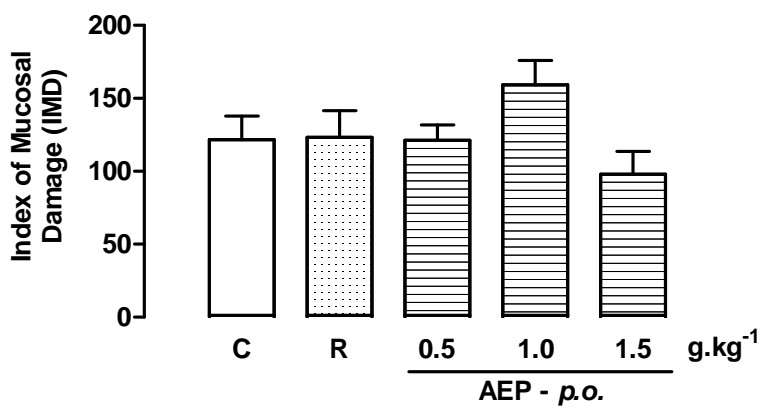

Figure 1 - Protective effect of crude aqueous extract of Pfaffia glomerata (Spreng) Pedersen (AEP) (C: control water, $0.5 \mathrm{ml} .100 \mathrm{~g}^{-1}$; R: $60 \mathrm{mg} \cdot \mathrm{kg}^{-1}-p o$ ) against gastric lesions induced by acetic acid. The data are means \pm s.e.m., $\mathrm{n}=6$ in all groups.

The AEP administration at the doses $0.5,1.0$ and $1.5 \mathrm{~g} . \mathrm{kg}^{-1}, p o$, was unable to protect the gastric mucosa against acetic acid induced ulcers, when the treatment was done at the first day after the surgery (prevention treatment) (Fig 1). However, on the healing treatment, the AEP enhanced the healing capacity of the mucosa, reducing the mucosal index damage at $62 \%$ (dose of $1.5 \mathrm{~g} \cdot \mathrm{kg}^{-1}$ ), when compared to the control parameters $(131,7 \pm$ 15,7) (Fig 2).

The histopathological examination of the gastric ulcer of the control group revealed the mucosal liquefaction, mucosal and submucosal edema, cells in mitosis, inflammation with macrophages and eosinophils, and proliferation of submucosal fibroblasts. The mucosal healing with the organization of submucosal fibroblasts, thicked muscular layer and absence of inflammatory cells were found in the ranitidine group. The oral treatment with the AEP $\left(1.5\right.$ g. kg $\left.{ }^{-1}\right)$ promoted the healing of the gastric mucosa with the presence of macrophages and necrosis of the fatty tissue (data not shown).
The test for the determination of acute toxicity $\left(50 \%\right.$ lethal dose $-\mathrm{LD}_{50}$ ) carried out on the mice indicated that the aqueous extract of the roots from Pfaffia glomerata (AEP) had low toxicity when administered orally (same route of administration as used in the folk medicine) since no animal deaths were observed with the doses from 1.0 to 10.0 g. $\mathrm{kg}^{-1}$ (maximal dose used in this test). However, the intraperitoneal administration of the AEP caused death of $50 \%$ of the animals with the dose of $684.6 \mathrm{mg} \cdot \mathrm{kg}^{-1}$, indicating a high toxicity of the AEP by this way. Previous studies showed the hydroalcoholic extract of Pfaffia sp presented $\mathrm{LD}_{50}$ value of $7.0 \mathrm{~g} . \mathrm{kg}^{-1}$ in $24 \mathrm{~h}$ and $6.5 \mathrm{~g} . \mathrm{kg}^{-1}$ in 14 days when the extract was administered by po (Paula et al., 1997). The results obtained suggested that the oral AEP presented lower acute toxicity than EHP. The difference of effects could be attributed to many factors such as the presence of different compounds (quantitative or qualitatively), type of the extraction (hydroalcoholic or aqueous), interaction between different compounds of the mixed roots, etc. In the hyppocratic test, many indicative signs were observed that AEP, 
independently of the way of administration, produced depression of the Central Nervous System activities, but the use of oral route only allowed the observations of these effects with higher doses to $4 \mathrm{~g} \cdot \mathrm{kg}^{-1}$, which were not used by the population.

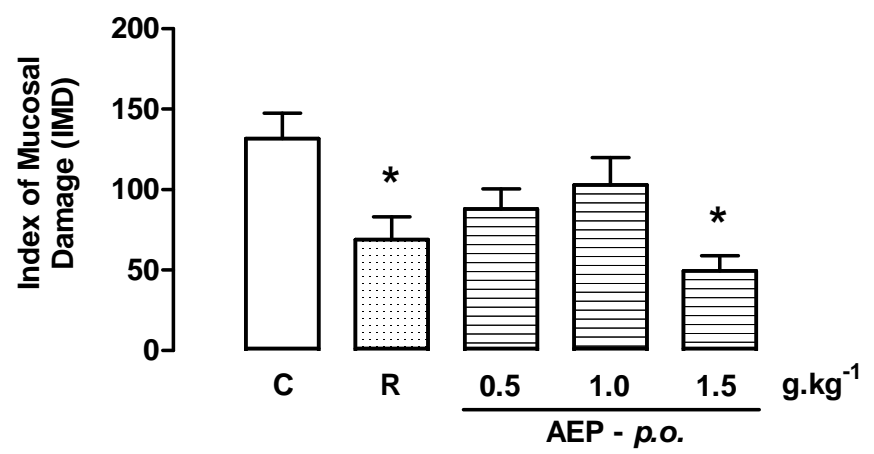

Figure 2 - Healing ulcer effect of crude aqueous extract of Pfaffia glomerata (Spreng) Pedersen (AEP) (C: control water, $0.5 \mathrm{ml} .100 \mathrm{~g}^{-1} ; \mathrm{R}: 60 \mathrm{mg} \cdot \mathrm{kg}^{-1}-p o$ ) against gastric lesions induced by acetic acid. The data are means \pm s.e.m., $\mathrm{n}=6$ in all groups. * different from the control group at $\mathrm{p}<0.05$.

The serosal application of acetic acid to induce the gastric ulcer in rats has been used as a convenient and reproducible model for the pharmacological study of the efficacy of antiulcer drugs (Tarnawski et al.,1990). A number of factors appeared to influence the ulcer healing. The luminal aggressive factors ( $\mathrm{HCl}$ secretion and pepsin) delay the ulcer healing. Inhibition of these factors by acid inhibitory drugs $\left(\mathrm{H}_{2}\right.$ blockers and proton pump inhibitors) is one of the major components of current peptic ulcer therapy (Tarnawski et al., 1995 and Robinson, 2004). Previous studies reported an antiacid action of the AEP (Freitas et al., 2004), which could contribute for the healing process that this extract presented. In addition, the AEP may enhance the mucus and bicarbonate secretion which are important factors in the ulcer healing process, because the mucus/bicarbonate layer protects newly formed cells from acid and pepsin injury. The gastric microvasculature has crucial role in the pathogenesis of acetic acid induced ulceration. The early vascular damage by acetic acid causes both isquemic damage and damage due to vascular congestion, free radicals formation and nutrient deficiency to the mucosal structures. All of these factors contribute to and amplify the damaging effect of acetic acid on the glandular cells. Besides, nitric oxide (NO) plays a role also in ulcer healing by stimulating the formation of growth factors, the epithelial proliferation and angiogenesis (Gyires, 2005). It was observed that AEP enhanced the NOx levels (Freitas et al., 2004) and then increased the blood flow and stimulated some events for the mucosal regeneration.

In conclusion, this study showed that the crude aqueous extract of Pfaffia glomerata seems to have a low toxicity and increased the gastric mucosa healing, probably through the inhibition of gastric acid secretion and/or the enhancement of the gastric nitric oxide production. These results reinforced the popularly indications of Pfaffia glomerata (Spreng) Pedersen for the gastric disturbances.

\section{RESUMO}

Pfaffia glomerata (Spreng) Pedersen (Amaranthaceae), uma planta conhecida popularmente como "Ginseng Brasileiro" e "paratudo", é utilizada para tratar distúrbios gástricos e como cicatrizante. Em estudos anteriores, foi demonstrado que o extrato aquoso bruto da $P$. glomerata (AEP) protegeu a mucosa gástrica contra úlceras induzidas por etanol e estresse e reduziu a secreção ácida gástrica basal e estimulada em ratos com ligadura de piloro. Além disso, a secreção gástrica de animais tratados com AEP apresentou níveis de nitrato e nitrito 
aumentados. O objetivo deste estudo foi avaliar se o AEP previne o desenvolvimento de úlceras induzidas por ácido acético e o efeito desse extrato no processo de cicatrização em úlceras previamente formadas. A administração do AEP em diferentes doses produziu efeitos tóxicos baixos e não preveniu a formação de úlceras, porém aumentou o processo de cicatrização em úlceras já existentes, como evidenciado no estudo histopatológico. Em conclusão, o AEP administrado cronicamente promove o aumento da cicatrização do tecido após a lesão induzida com o ácido acético.

\section{REFERENCES}

Freitas, C. S.; Baggio, C. H.; Silva-Santos, J. E.; Rieck, L.; Santos, C. A. M.; Corrêa Jr, C.; Ming, L. C.; Cortez, D. A. G.; Marques, M. C. A. (2004), Involvement of nitric oxide in the gastroprotective effects of an aqueous extract of Pfaffia glomerata (Spreng) Pedersen, Amaranthaceae, in rats. Life Sciences, 74, 1167-1179.

Freitas, C. S.; Paula, M. F. R.; Rieck, L.; Marques, M. C. A. (2003), Actions of crude hydroalcoholic extract of Pfaffia sp on gastrointestinal tract. Brazilian Archives of Biology and Technology, 46 (3), 355-360.

Gyires, K. (2005), Gastric mucosal protection: from prostaglandins to gene-therapy. Current Medicinal Chemistry, 12 (2), 203-215.

Nakai, S. (1984), Pfaffosides and nortriterpenoid saponins from Pfaffia paniculata. Phytochemistry, 23(8), 1703-1705.

Nishimoto, N.; Nakai, S.; Takagi, N.; Hayashi, S.; Takemoto, T.; Odashima, S.; Kizu, H.; Wada, Y. (1984), Pfaffosides and nortriterpenoids saponins from Pfaffia paniculata. Phytochemistry, 23 (1), 139142.

Oliveira, F. (1986), Pfaffia paniculata (Martius) Kuntze - O ginseng-brasileiro. Revista Brasileira de Farmacognosia, 1(1), 1-117.

Robinson, M. (2004), Review article: pH, healing and symptom relief with rabeprazole treatment in acidrelated disorders. Alimentary Pharmacology and Therapeutics, 20 (6), 30-37.

Shiobara, Y.; Inoue, S. S.; Kato, K.; Nishiguchi, Y.; Oishi, Y.; Nishimoto, N.; Oliveira, F.; Akisue, G.; Akisue, M. K.; Hashimoto, G. (1993), A nortriterpenoid, triterpenoids and ecdysteroids from Pfaffia glomerata. Phytochemistry, 32 (6), 15271530.

Takagi, E.; Okabe, S.; Saziki, R. (1969), A new method for the production of chronic gastric ulcer in rats and the effect of several drugs on healing. Japanese Journal of Pharmacology, 19, 416-426.

Takemoto, T. (1983), Pfaffic acid, a novel nortriterpene from Pfaffia paniculata Kuntze. Tetrahedron Letters, 24 (10), 1057-1060.

Tarnawski, A.; Hollander, D.; Stachura, J.; Krause, W.J.; Eltorai, M.; Dabros, W.; Gergely, H. (1990), Vascular and microvascular changes - key factors in the development of acetic acid-induced gastric ulcers in rats. Journal of Clinical Gastroenterology, 12 (1), 148-157.

Tarnawski, A.; Tanoue, K.; Santos, A. M.; Sarfeh, I. J. (1995), Cellular and molecular mechanisms of gastric ulcer healing. Is the quality of mucosal sacr affected by treatment? Scandinavian Journal of Gastroenterology, 30 (210), 9-14.

Litchfield, J.T. and Wilcoxon, F. (1948), Simplied method of evaluating dose-effect experiments. Americam Cyanamid Company, Stanford Research Laboratory, Connecticut.

Malone, M.H. (1977), Pharmacological approaches to natural products screening and evaluation, in Wagner $\mathrm{H}$, Wolf $\mathrm{P}$ (eds), Natural products and plant drugs with pharmacological, biological or therapeutical activity. Springer-Verlag, Berlin, 23-53.

WHO (World Health Organization). Council for International Organizations of Medical Sciences (CIOMS) (1993), International Ethical Guidelines for Biomedical Research Involving Human Subjects. Geneva.

OECD (Organization For Economic Co-Operation And Development) (1998), Guideline 408: subchronic oral toxicity - Rodent: 90 - Days. Paris.

Paula, M.F.R ; Freitas, C.S.; Nowacki, L.C.; Strapasson, F.; Vela, S.M.; Marques, M.C.A. (1997), Avaliação preliminar dos efeitos do extrato hidroalcoólico da Pfaffia sp sobre o trato gastrointestinal. Anais da XII Reunião Anual da Federação de Sociedades de Biologia Experimental (FeSBE), 357. 